\author{
V.S. Portnov ${ }^{1}$, L.K. Novikova ${ }^{1}$, S.A. Vyzhva ${ }^{2}$, N.V. Reva ${ }^{2}$, \\ A.R. Baizhanova ${ }^{1}$, V.M. Yurov ${ }^{3}$, A.D. Maussymbayeva ${ }^{1}$ \\ ${ }^{1}$ Karaganda State Technical University, Kazakhstan; \\ ${ }^{2}$ Kiev National University of Taras Shevchenko, Ukraine; \\ ${ }^{3}$ Ye.A. Buketov Karaganda State University, Kazakhstan \\ (E-mail: exciton@listl.ru)
}

\title{
Crushing and grinding minerals deposits of the western area Nurkazgan
}

\begin{abstract}
The paper calculated the total surface energy of the mineral deposits Nurkazgan West, which is equal to: $\sigma=0,806 \mathrm{~J} / \mathrm{m}^{2}$. The main contribution to the surface energy of the field West Nurkazgan minerals contribute quartz $\left(\mathrm{SiO}_{2}\right)$ and corundum $\left(\mathrm{Al}_{2} \mathrm{O}_{3}\right)$. Designed overall operation of the fragmentation of 1 ton of mineral deposits Nurkazgan to a piece of $5 \mathrm{~mm}$, which is $\mathrm{A}=3.014 \mathrm{~J}$. This corresponds to a specific energy consumption $\mathrm{E}=30.2 \mathrm{~kW} \cdot \mathrm{h} / \mathrm{t}$. It shows that to increase the efficiency of ore crushing need to increase the defects of the mineral structure, reduce the temperature and increase the power of crushing. Cooling is best in ore hopper using liquid cryogenic plants. It is shown that an abrupt change of work crushing and defects in the mineral structure can be achieved with the optimal use of energy in the blast ore production stage or electroimpulse crushing hopper. It is shown that the minimum value of the grain size is determined by the surface energy: mind $\rightarrow \min ^{2}$. This condition determines the efficiency of ore grinding. To increase it is necessary to decrease the surface energy minerals. It is shown that the most cost-effective mix before the process of crushing and grinding the ore Western and Northern regions Nurkazgan field.
\end{abstract}

Keywords: surface energy, ore, mineral, crushing, grinding, copper, chalcopyrite, structural defects.

\section{Introduction}

The process of ore dressing in the technologies of various ores enrichment is aimed at creating conditions that provide the maximum degree of extraction of useful component at the lowest possible resource consumption. Generally, this process involves grinding the ore to a particle size less than the smaller of the useful component of grain with subsequent extraction of one or another physical or chemical means.

The most energy-intensive and costly process in the extraction and enrichment of mineral raw materials is their destruction. For example, in the iron ore beneficiation plants in the Russian share of this process accounts for $70 \%$ of all energy consumption $(30 \mathrm{~kW} \cdot \mathrm{h} /$ ton of ore) [1]. Fracture of all technological processes, and this drilling, blasting, crushing and grinding, milling is the most energy-intensive $(26 \mathrm{~kW} \cdot \mathrm{h} /$ ton of ore $)$ [1]. In the US, the share of mining crushing and grinding accounted 29.3 billion kilowatt-hours per year [2], representing $45 \%$ of total US electricity consumption mining industry.

In this paper we will use the results of the thermodynamic analysis of the fracture process, following [3], which shows an extensive bibliography on the issues raised.

\section{The mineral composition of the western portion of the deposit Nurkazgan}

Ores West area aresulphide gold-copper. Rock-forming minerals are: (average of the laboratory process samples) silica $34.5 \%$; feldspar $27.0 \%$; sericite, muscovite $25.0 \%$; chlorite $5.0 \%$ and $4.0 \%$ calcite. The basic value of the ore are copper, gold, concomitant are silver, molybdenum, selenium, tellurium, indium, and pyritic sulfur, platinum, palladium.

A characteristic feature of mineralization is that the discharge size of chalcopyrite and pyrite vary widely: from very thin and thin, to small and large inclusions of solid masses. The texture of ore isolations: breeding and sparsely interspersed. Table 1 shows the average contents of fields in Western Nurkazgan minerals.

$\mathrm{Tab} l \mathrm{e} 1$

Percentage of deposits of minerals West Nurkazgan

\begin{tabular}{|c|c|c|c|}
\hline The mineral & Percentage, $\%$ & The mineral & Percentage, $\%$ \\
\hline $\mathrm{SiO}_{2}$ & 63,81 & $\mathrm{MnO}$ & 0,08 \\
\hline $\mathrm{TiO}_{2}$ & 0,41 & $\mathrm{MgO}$ & 1,20 \\
\hline $\mathrm{Al}_{2} \mathrm{O}_{3}$ & 17,34 & $\mathrm{CaO}$ & 2,50 \\
\hline $\mathrm{FeO}$ & 3,95 & $\mathrm{~K}_{2} \mathrm{O}$ & 4,20 \\
\hline $\mathrm{Fe}_{2} \mathrm{O}_{3}$ & 1,51 & $\mathrm{Na}_{2} \mathrm{O}$ & 0,18 \\
\hline
\end{tabular}




\section{The calculation of the surface energy of ores and minerals deposits \\ of the western section of Nurkazgan}

The specific surface energy (surface tension) - the main characteristic of processes involving surfaces or phase boundaries. Surface tension determines the free energy (work) that must be expended to form a unit of surface area or interface.

Surface phenomena occur in any heterogeneous system consisting of two or more phases. In essence, the entire material world - is heterogeneous. As a homogeneous system may be considered only in limited space volumes. Therefore, the role of surface phenomena in natural and technological processes is extremely high.

The use of surface phenomena in the production of human activity allows to intensify the existing processes. Surface phenomena largely determine ways of obtaining and durability of major building and construction materials; the efficiency of extraction and processing of minerals. The presence of surface tension is due to the fact that the atoms on the surface of the liquid or solid state have a greater potential energy than the atoms or ions within them, so the surface energy is usually regarded as an excess power per unit area.

When grinding minerals to sizes close to molecular, dispersed work per unit of the newly formed surface (specific surface energy) is between $410^{-4} 10^{-3}$ to $2.7 \mathrm{~J} / \mathrm{cm}^{2}$. The product of $A=\sigma \cdot S$ is a dispersing operation, where $\sigma$ - surface tension (surface energy) of the mineral, and $\mathrm{S}$ - its specific surface area.

Table 1 shows the mineral composition of deposits West Nurkazgan. We calculate according to [3], the surface energy of these minerals (Table 2).

Table 2 shows that practically all oxides except monoxides iron, manganese, potassium and sodium dioxide, have high surface energy.

If we use the equation of Rettinger [3], we get:

$$
\mathrm{A}=\gamma \Delta \mathrm{S}=\sigma \cdot \Delta \mathrm{S}
$$

where $\gamma$ - temporary resistance to compression $\left(\mathrm{N} \cdot \mathrm{m} / \mathrm{m}^{2}\right), \Delta \mathrm{S}$ - area of newly formed surface $\left(\mathrm{m}^{2}\right)$.

Equation (1) shows that the quantity $\sigma=\gamma$. This allows you to compare our calculations with tabulated values temporary compression resistance (tensile strength) [4].

Table 3 shows the comparison for the known compounds. Table 3 shows that, up to a tenth of the surface energy and ultimate strength are the same minerals. This allows evaluation of these values in the case where one of them is unknown.

Table 2

Surface energy field West Nurkazgan minerals

\begin{tabular}{|c|c|c|c|}
\hline The mineral & Surface energy $\left(\mathrm{J} / \mathrm{m}^{2}\right)$ & The mineral & Surface energy $\left(\mathrm{J} / \mathrm{m}^{2}\right)$ \\
\hline $\mathrm{SiO}_{2}$ & 0,655 & $\mathrm{MnO}$ & 0,396 \\
\hline $\mathrm{TiO}_{2}$ & 0,633 & $\mathrm{MgO}$ & 0,359 \\
\hline $\mathrm{Al}_{2} \mathrm{O}_{3}$ & 0,715 & $\mathrm{CaO}$ & 0,436 \\
\hline $\mathrm{FeO}$ & 0,401 & $\mathrm{~K}_{2} \mathrm{O}$ & 0,131 \\
\hline $\mathrm{Fe}_{2} \mathrm{O}_{3}$ & 0,707 & $\mathrm{Na}_{2} \mathrm{O}$ & 0,143 \\
\hline
\end{tabular}

T a b l e 3

Surface energy and strength of some minerals

\begin{tabular}{|c|c|c|}
\hline The mineral & $\begin{array}{c}\text { Surface energy } \\
\left(\mathrm{J} / \mathrm{m}^{2}\right)\end{array}$ & $\begin{array}{c}\text { The } \\
\text { strength }\left(\mathrm{J} / \mathrm{m}^{2}\right)\end{array}$ \\
\hline $\mathrm{SiO}_{2}$ & 0,655 & 0,589 \\
\hline $\mathrm{TiO}_{2}$ & 0,633 & 0,615 \\
\hline $\mathrm{Al}_{2} \mathrm{O}_{3}$ & 0,715 & 0,680 \\
\hline $\mathrm{MgO}$ & 0,359 & 0,396 \\
\hline
\end{tabular}

We now make a calculation of the total surface energy of the mineral deposits West Nurkazgan using its additive property. Table 1 shows the average contents of fields in Western Nurkazgan minerals.

Given in Table 1 the total surface energy of the West Nurkazgan deposits of minerals will be equal to:

$$
\sigma=0,806 \mathrm{~J} / \mathrm{m}^{2} \text {. }
$$


The main contribution to the surface energy of the field West Nurkazgan minerals contribute quartz $\left(\mathrm{SiO}_{2}\right)$ and aluminum oxide $\left(\mathrm{Al}_{2} \mathrm{O}_{3}\right)$.

\section{Efficiency ore crushing}

Crushing in the broadest sense is the process of reducing the size of the pieces of ore or grain so their value at which minerals can be separated from each other by subsequent enrichment process.

At the ore processing plant is supplied in pieces of different sizes, from 200-300 up to $1500 \mathrm{~mm}$, depending on the nature of the ore and mining. These pieces consist of a splice minerals and are not suitable for enrichment.

The ore in this case should be subject to a preliminary crushing, and the final size of the pieces is determined mainly by the nature of impregnation of mineral grains in ore (large, small or thin impregnation).

Crushing can be carried out in several ways: crushing, abrasion, splintering, stroke and combination methods listed above. In some cases, they are joined by more side effects of tearing or bending forces.

Crushing - one of the most expensive processes. On concentrators cost of the crushing process is on average $40 \%$ of the ore enrichment and the cost of crushing equipment - about $60 \%$ of the cost of factory equipment. Therefore crushing principle is «do not crush nothing more». Compliance with this principle provides energy savings, increased plant capacity, reducing the useful mineral loss and decrease wear of working parts of crushers.

To fulfill the principle of «do not crush nothing more» whole crushing operation is divided into several steps or techniques; before crushing stage provides each classification in order to separate fines in order not to subject the pieces of size ready re-crushed, and finally, if applicable, after each cleavage step used enrichment.

Distinguish: a large crushing — by crushing the ore from 1500 to $100-400 \mathrm{~mm}$; secondary crushing from 400-100 to 30-50 $\mathrm{mm}$ and fine crushing - from 30-50 to 3-5 mm. Finer division (less than $1 \mathrm{~mm}$ ) refers to breakage.

Large, medium and fine crushing is carried out in devices known as crushers (jaw, cone, etc.).

Selection crushing method, and consequently, the crusher type depends on the physical properties of the material to be crushed, and the size of its initial size and the desired cleavage product. For solids and viscous materials it is the most efficient crushing crushing, impact and abrasion, while brittle materials it is advisable to split splintering.

Large and medium crushing is carried out mainly by crushing and splintering and crushing — impact and abrasion.

According to [5] in the area of mine development West porphyry copper deposits developed Nurkazgan rocks with hard crystalline bonds, among which are the basic intrusive ore-bearing formation. The on-board parts of the volcanic rocks occur presented basaltic andesite tuffs composition. According to the physical properties of the body and breed pit walls vary within a small range. Several different from other indicators of intrusive breccias, demonstrating a high density $\left(2.80 \mathrm{~g} / \mathrm{cm}^{3}\right)$, increased weight $\left(2.84 \mathrm{~g} / \mathrm{cm}^{3}\right)$ and higher water absorption $(0.33 \%)$. Mechanical properties of intrusive breccias with less. Tensile strength under uniaxial compression at $35.61 \mathrm{MPa}$ breccias, tuffs at - 42.16, the remaining species is in the range $56,69-57,89 \mathrm{MPa}$.

When saturated with water, the compressive strength decreases from quartz diorite to $11 \%, 20 \%$ granodiorite, intrusive breccia at 29\%,26\% tuff. As seen from the above figures, the ratio of the strength properties in the water-saturated state is proportional to their ratio in the dry state. Intrusive breccias and tuffs of the most affected by water cut.

According to [6], the total amount of materials annually subjected to disintegration of 3-3.5 bln. tons, and power consumption for these processes is $4.5-5 \%$ of the total production in the country. The weight of crushing and grinding equipment, processing 1 million ton mountain of raw materials per year, an average of 1 ths. tons. Much of the metal ( 1 to $3 \mathrm{~kg}$ per 1 ton of ore and pulverized crushability, depending on its characteristics and fineness) is irretrievably lost as a result of abrasive wear and the corrosion of grinding bodies and linings of organs working machines. In general, irrecoverable losses of metal in the process of disintegration of the mineral raw materials account for up to 4 million tons per year, or $2 \%$ of its total production in the country.

If we consider that the average density of mineral deposits Nurkazgan $\rho=2,8 \mathrm{~g} / \mathrm{cm}^{3}$, then 1 ton of ore will occupy the volume $\mathrm{V}=0,36 \mathrm{~m}^{3}$. The sphere approximation, its surface area is equal to: $\mathrm{S}=0,64 \mathrm{~m}^{2}$ and an average diameter of $\mathrm{d}=0,9 \mathrm{~mm}=900 \mathrm{~mm}$. Table 4 is computed using equation (2), work crushing Nurkazgan minerals deposits. 
Work for large, medium and fine crushing of mineral deposits Nurkazgan

\begin{tabular}{|c|c|c|c|}
\hline & $\begin{array}{c}\text { Coarse crushing, } \\
\text { from } 900 \text { to } 100 \mathrm{~mm}\end{array}$ & $\begin{array}{c}\text { Secondary crushing, } \\
\text { from } 100 \text { to } 30 \mathrm{~mm}\end{array}$ & $\begin{array}{c}\text { Fine crushing, } \\
\text { from } 30 \text { to } 5 \mathrm{~mm}\end{array}$ \\
\hline Workcrushing, J & 1,612 & 1,241 & 0,161 \\
\hline
\end{tabular}

Thus, the overall operation of the fragmentation of 1 ton Nurkazgan mineral deposits of up to $5 \mathrm{~mm}$ in size will be 3,014 pieces of $\mathrm{J}$.

The specific energy consumption of mechanical disintegration in stages depending on the strength characteristics of the ore from the literature are as follows, $\mathrm{kW} \cdot \mathrm{h} / \mathrm{t}[6]$ :
coarse crushing
$0.3-0.5$
medium and fine crushing
$0.8-1.2$
coarse and fine grinding
$18-20$
ultrafine grinding
50

In Table 5, calculated using equation (2), the specific energy consumption for crushing minerals Nurkazgan field.

Table 5

Energy costs for large, medium and fine crushing of mineral deposits Nurkazgan

\begin{tabular}{|c|c|c|c|}
\hline & $\begin{array}{c}\text { Coarse crushing, } \\
\text { from } 900 \text { to } 100 \mathrm{~mm}\end{array}$ & $\begin{array}{c}\text { Secondary crushing, } \\
\text { from } 900 \text { to } 30 \mathrm{~mm}\end{array}$ & $\begin{array}{c}\text { Fine crushing, } \\
\text { from } 900 \text { to } 5 \mathrm{~mm}\end{array}$ \\
\hline $\begin{array}{c}\text { Specific energy consumption } \\
\mathrm{kW} \cdot \mathrm{h} / \mathrm{t}\end{array}$ & 0,45 & 0,80 & 1,29 \\
\hline
\end{tabular}

Table 5 shows that the energy consumption for crushing Nurkazgan mineral deposits fall into the general classification [6].

We use the formula for the efficiency of ore crushing, obtained in [3]:

$$
\eta=\frac{k T}{C_{1}} \cdot \frac{A}{G^{0}} \cdot \bar{N}
$$

where $A$ - work (energy) crushing, $T$ - temperature, the $G^{0}$ - Gibbs potential of a bulk sample of the mineral, $N$ - the average number of elementary media destruction (proportional to the number of defects), $C_{1}$ - constant.

Chalcopyrite - is the main ore-forming mineral of copper ores of the Western region (84.9\% rel.). Most often, it forms a nest-solid mass accumulation irregular, angular shape often ranging in size from $0.5 \mathrm{~mm}$ to $2 \times 5 \times 8 \mathrm{~cm}$ in size of individual grains of 0.01-0.5 mm [46].

Often the borders of enlarged grains of chalcopyrite observed subtle and very subtle highlight it sometimes in the form of dispersion haloes, the size of the first microns to 0.01-0.02 mm. Sometimes veinlets of chalcopyrite inclusions in the rock go into intermittent, size $(0,016-0,280 \mathrm{~mm})$.

To happened disclosure of mineral chalcopyrite phase, hence the need to perform work (equation 2, a piece the size of chalcopyrite $-0.5 \mathrm{~mm}$ ). $\mathrm{A}=3.022 \mathrm{~J}$. This corresponds to a specific energy consumption $\mathrm{E}=30.2 \mathrm{~kW} \cdot \mathrm{h} / \mathrm{t}$. This is a fairly significant energy costs.

CJSC «Mekhanobr Engineering» (Moscow, Russia) at the request of JSC «Kazakhmys Corporation» tested the impact of off-balance sheet crushing of sulphide ores of Zhezkazgan field in the high-pressure roller mill LABWAL compared to crushing ore in Zhezkazgan standard roll crusher energy consumption during grinding of crushed ore. It is shown that at a final grind size of $65 \%$ of class $-0.074 \mathrm{~mm}$ in the specific consumption of useful energy for grinding the ore after the passage of the high pressure roll crusher LABWAL was $15.23 \mathrm{~kW} \cdot \mathrm{h} / \mathrm{t}$, and after crushing in a standard roll crusher $-16.6 \mathrm{~kW}-\mathrm{h} / \mathrm{t}$. The total consumption of useful energy for crushing and grinding was respectively 18.06 and $22.2 \mathrm{~kW} \cdot \mathrm{h} / \mathrm{t}$. These obtained values are close to us. The differences relate to the greater strength of the rocks western section Nurkazgan deposits compared to off-balance sheet deposits of sulfide ores of Zhezkazgan.

Given that $\mathrm{G}^{0}=\mathrm{a}+\mathrm{bT}+\mathrm{cT}^{2} \approx \mathrm{cT}^{2}$, rewrite (3) in the form of:

$$
\eta=C \cdot \frac{A}{T} \cdot \bar{N}
$$

where $C-$ a constant. From equation (4) it follows that to increase the ore crushing efficiency must be increased deficiency of the mineral structure, reduce the temperature and increase the energy division. Figure is a schematic diagram of ore preparation Nurkazgan field. 
A sharp change in the ore reduction in temperature leads to an increase in the efficiency of its fragmentation - the formula (4). This is due to the uneven expansion of the ore and form a plurality of micro-cracks. This method has found application and called cryogenic disintegration of refractory ores [7]. Cooling is best in ore hopper (Fig. 1) using liquid cryogenic plants [8].

The sharp change in operation of crushing and defects in the structure of formula (4) can be achieved with optimum utilization of the energy of the explosion $[9,10]$ to ore extraction step or crushing electropulse [11] in the hopper.

Currently, about $90 \%$ of non-ferrous and ferrous metals mined by blasting. Most researchers believe criterion for evaluating how damaging and crushing action of the explosion energy of the total explosive (HE) [12, 13].

For different types of explosives as the primary criterion for evaluation taking energy per unit concentration rechargeable cavity in a product, $\rho$ A where A — perfect job explosion $\mathrm{kJ} / \mathrm{kg} ; \rho$ — density cartridge patronize or loading density granular explosives, $\mathrm{g} / \mathrm{cm}^{3}\left(\mathrm{~kg} / \mathrm{dm}^{3}\right)$.

With the explosion of $1 \mathrm{~kg}$ of TNT energy is released about $4 \cdot 106 \mathrm{~J}$ Above, we calculated the energy splitting of 1 ton of minerals western section Nurkazgan deposits - 3,022 G. When blasting operations efficiency (efficiency) of the explosion is extremely low: From 1 to $7 \%$ by explosions on emissions and 15-25\% in the explosions at crushing of rocks $[12,13]$. Therefore, only about $106 \mathrm{~J} 0,6 \bullet 1 \mathrm{~kg}$ of TNT explosion goes to ragging. For grinding 1 ton of mineral deposits of the West section Nurkazgan therefore need about $5 \mathrm{mg}$ or TNT explosives in the same TNT.

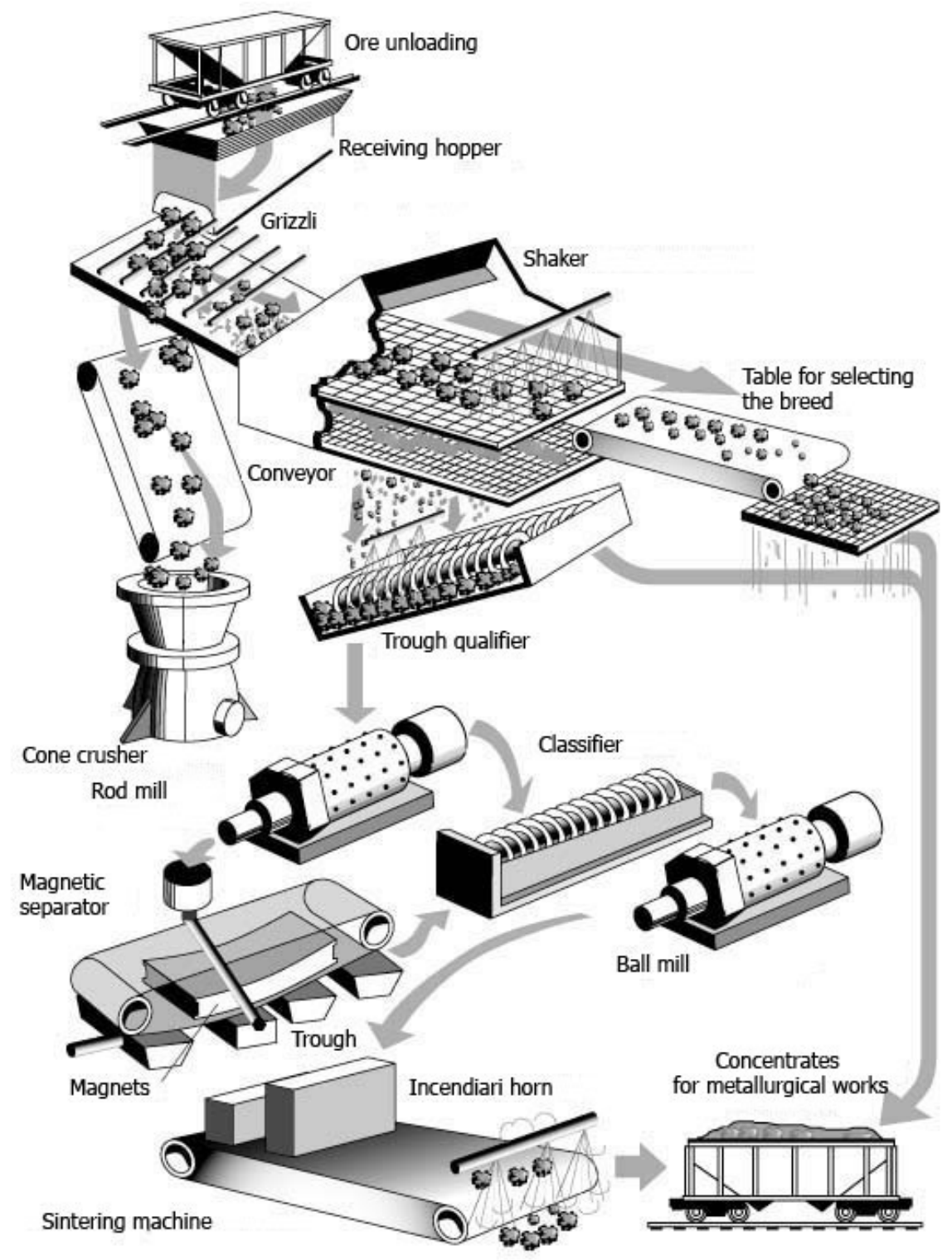

Figure. The scheme for obtaining concentrate Nurkazgan field 
Promising use for crushing minerals western part of the deposit Nurkazgan electro technology [11]. Features of this technology are realized in a disintegrator to electro KLEID [13], which can be manufactured in a hopper (Fig.).

For electroimpulse crushing important to know the «resonant frequency» of the mineral, which can be represented as:

$$
\omega_{\text {pes }}=\sqrt{\frac{\lambda}{c \rho}}
$$

where $\lambda$ - thermal conductivity, $c$ - specific heat, $\rho$ - density of the medium.

Chalcopyrite - is the main ore-forming mineral of copper ores of the Western region $(84.9 \%$ rel.). For him, according to [4]: $c=534.3 \mathrm{~J} / \mathrm{kg} \mathrm{K}, \rho=4,1 \mathrm{~kg} / \mathrm{m}^{3}$, and according to [14]: $\lambda=9 \mathrm{~W} / \mathrm{m} \mathrm{K}$. Then the resonance frequency of the chalcopyrite: $\omega_{\text {rez }} \approx 2 \mathrm{~Hz}$. This is an achievable rate for electropulse technologies.

\section{Optimization of grinding ore}

The effectiveness of grinding ore determines the profitability of the field development. Thus, these models are required grinding processes that describe the use of energy devices destructive action (crushers, mills, disintegrating agents) in the ore, and could be used to solve practical problems of optimization of the grinding cycle.

This model considers the comminution process in terms of two aspects $[15,16]$ :

- grindability ore, particularly by applying a certain amount of specific energy;

- characteristics of grinding equipment - the quantity and nature of the type of energy and movement of ore through the apparatus.

Models grinding process the particles are separated into two classes [16]:

- a model in which it is assumed that the milling equipment is the particle size distribution of the transducer between nutrition and the final product;

- the model is considered in which each element in the grinding process.

These classes were assigned to the model of the «black box» and «basic model», respectively. The first class of models is widely used at present. The second class requires huge computational resources, and become economically viable for future use.

The task of the fundamental models generate a detailed link between the physical conditions inside the machine and the result of the process that takes place in it. A limitation of this type of modeling is a computational technique. Many scholars have devoted their work to research the issue [17-19]. For example, in [20] it was proposed to divide the mill in the area: shock, friction / abrasion and impact of small and describe each zone separately, thus reducing the requirements applicable in the simulation of digital technology.

We emphasize that the grinding is fundamentally different from the crushing presence in its process of «size effect». Experimental investigation of mechanical properties of nanomaterials have shown that the tensile strength, hardness, many metals ( $\mathrm{Pd}, \mathrm{Cu}, \mathrm{Ag}, \mathrm{Ni}$ et al.) Is significantly higher than the corresponding bulk analogues $[21,22]$. Increased strength and hardness with decreasing grain size up to a certain critical size is typical for virtually all crystals. This follows from the Hall-Petch equation that the yield stress depends inversely $\gamma_{\mathrm{T}}$ of the average grain size $\mathrm{d}[22]$ :

$$
\gamma_{T}(d)=\gamma_{M}+k d^{-1 / 2}
$$

$\gamma_{\mathrm{M}}$ - where the limit strength of the single crystal, $k$ - coefficient of some dimension.

In [23] to the yield strength obtained:

$$
\gamma_{T}(d)=\gamma_{M}+C \sigma d^{-1 / 2}
$$

Equation (7) coincides in shape with the Hall-Petch equation (6). However, the coefficients of proportionality differ in both formulas. In this case, the behavior of the yield strength of small particles is also determined by the size of their surface tension $\sigma$.

From equation (7) implies that $d \sim \sigma^{2}$. In other words, the minimum value of the grain size is determined by:

$$
\min d \rightarrow \min \sigma^{2} .
$$

Condition (8) defines the efficiency of ore grinding. To increase it is necessary to decrease the surface energy minerals.

According to [5] for the northern part of the deposit Nurkazgan copper mineralization is mainly chalcopyrite, a very small amount presentbornite and covellite. The ore contains pyrite, magnetite, hematite. 
The main components are copper, wherein the content selected by the ore bodies ranges from 0.18 to $1.66 \%$ with an average of $0.46 \%$ and the gold content of $0.27 \mathrm{~g} / \mathrm{m}$. The samples set group silver $-2.15 \mathrm{~g} / \mathrm{t}$ of molybdenum - $0.0065 \%$ selenium $-2.71 \mathrm{~g} / \mathrm{t}$, pyrite sulfur $-0.65 \%$ of impurities harmful mercury $0.16 \mathrm{~g} / \mathrm{m}$ and thallium $-0.54 \%$. The content of tellurium, indium, arsenic and antimony below the detection threshold of the quantitative analyzes.

The total surface energy of the minerals of the Northern area Nurkazgan field according to our estimates of $\sigma=0,576 \mathrm{~J} / \mathrm{m}^{2}$. This is $30 \%$ less than the surface energy of the mineral deposits of the West section Nurkazgan $\left(\sigma=0,806 \mathrm{~J} / \mathrm{m}^{2}\right)$.

Thus, the most cost-effective mix before the process of crushing and grinding the ore Western and Northern regions Nurkazgan field. The same conclusion on the basis of experimental studies and came to the authors of [24].

With decreasing particle size of the defects of its structure is reduced due to the disappearance of dislocations sources. In this case, you can use the powerful nanosecond electromagnetic pulses [25], while the pulse generator is better to install the ball mill in Figure 1

\section{Conclusion}

One of the first scientists to investigate in detail the properties of the surfaces of discontinuity between the various solids, was an outstanding American physicist and mathematician Josiah Willard Gibbs. In his famous work «On the equilibrium of heterogeneous substances», which later became the foundation of the modern thermodynamics, Gibbs was first considered as a separate subsystem surface other than the shared its thermodynamic phase. This surface layer although it has a very small thickness, but is, according to Gibbs, a definite «phase», that is the state of matter with its inherent energy, entropy and other thermodynamic quantities. This approach allowed Gibbs to create a macroscopic theory of surface phenomena to explain and quantify adsorption, that is, the ability of surface to absorb molecules from the environment.

In this work we wanted to show the importance of the knowledge of the properties of the surface layer in a very important technological processes of crushing and grinding of ores and minerals.

\section{References}

1 Чантурия В.А. Современные проблемы обогащения минерального сырья в России // Горный журнал. — 2005. № 12. - C. 13-19.

2 Hague K.E. Microwave energy of mineral treatment processes — a brief review // Int. J. Miner. Process. — 1999. — № 57. - P. 146-154.

3 Портнов В.С., Юров В.М., Ахметов А.С. Энергия диспергирования упорных руд и минералов. - Караганда: КГТУ, 2014. - $160 \mathrm{c}$.

4 Физические свойства горных пород и полезных ископаемых: Справочник геофизика / Под ред. Н.Б. Дортман. - М.: Недра, 1984. - 455 с.

5 Отчет по поисково-разведочным работам на месторождении Нурказган с подсчетом запасов по состоянию на 01.07.2004 г. Контракт № 109 от 28.02.97 г., дополнение к контракту № 984 от 18.09.02 г. В 8 книгах. — Жезгазган, 2005.

6 Сажин Ю.Г. Процессы рудоподготовки и оборудование. - Алматы: КазНТУ, 2011. — 138 с.

7 Татауров С.Б. Совершенствование геотехнологии. - кучного выщелачивания золота с применением криогенной дезинтеграции руд // Записки горного института. — 2011. — Т. 190. — С. 126-131.

8 Зайцев А.B. Криогеника в начале XXI века // Научный журнал НИУ ИТМО. Серия «Холодильная техника и кондиционирование». — 2014. - № 1. - С. 6-12.

9 Кутузов Б.Н. Методы ведения взрывных работ. Ч. 2. Взрывные работы в горном деле и промышленности. - М.: Горная кн., 2008. - 512 c.

10 Юсупов Х.А., Кабетенов T. Технология отработки маломощных рудных залежей на основе взрыворазделения. Алматы: Экономика, 2013. - 136 с.

11 Куреи В.И., Усов А.Ф., Цукерман В.А. Электроимпульсная дезинтеграция материалов. - Апатиты: Изд. Кольского научного центра РАН, 2002. - $324 \mathrm{c}$.

12 Росси Б.Д., Поздняков 3.Г. Промышленные взрывчатые вещества и средства взрывания. — М.: Недра, 1971. — 176 с.

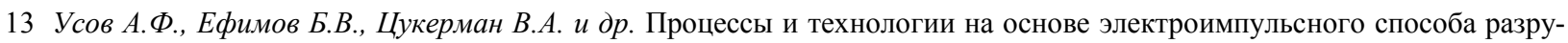
шения материалов // Инновационный потенциал Кольской науки. - Апатиты: Изд. Кольского научного центра РАН, 2005. - C. 306-312. 
14 Попов В.В., Кижаев С.А., Рудь Ю.В. Магнитные и тепловые свойства $\mathrm{CuFeS}_{2}$ при низких температурах // Физика твердого тела. - 2011. - Т. 53. - Вып. 1. - С. 70-74.

15 Андреев С.Е., Перов В.А., Зверевич В.В. Дробление, измельчение и грохочение полезных ископаемых. - М.: Недра, 1980. - $415 \mathrm{c}$.

16 Алексеева E.A. Получение малокремнистого алюминиевого сырья в процессе рудоподготовки низкокачественных бокситов: Дис. ... канд. техн. наук. - СПб., 2015. - 183 с.

17 Mishra B.K., Rajamani R.K. Analysis of media motion in industrial mills // Comminution: Theory and Practice, Ed: Kawatra, 1992. - P. 427-440.

18 Mishra B.K., Rajamani R.K. Simulation of charge motion in ball mills. Part 1: experimental verifications // Int J of Min Proc. — 1994. - Vol. 40. - P. 171-186.

19 Mishra B.K., Rajamani R.K. Simulation of charge motion in ball mills. Part 2: numerical simulations // Int J of Min Proc. 1994. - Vol. 40. - P. 187-197.

20 Radziszewski P., Tarasiewicz S. Autogenous mill design using comminution energetic// SAG'89 - Advances in autogenous and semiautogenous grinding technology. Ed.: Mular and Agar. - Vancouver, 1989. - P. 773-778.

21 Андриевский Р.Л., Глезер А.М. Прочность наноструктур // Успехи физических наук. — 2009. — Т. 179. — № 4. — C. 337-358.

22 Малыгин Г.А. Прочность и пластичность нанокристаллических материалов и наноразмерных кристаллов // Успехи физических наук. - 2011. - Т. 181. - № 11. - С. 1129-1156.

23 Юров В.М., Лауринас В.Ч., Гученко С.А. Некоторые вопросы физики прочности металлических наноструктур // Физико-химические аспекты изучения кластеров, наноструктур и наноматериалов: межвуз. сб. науч. тр. — Тверь: Твер. гос. ун-т, 2013. - Вып. 5. - С. 408-412.

24 Максимов И.И., Отрожденнова Л.А., Тасина Т.И., Заварина Р.И., Егорова В.Г. Изучение обогатимости руд Западного и Северного участков месторождения Нурказган с различным содержанием меди // Обогащение руд. - 2014. — № 3. C. $8-16$.

25 Бунин И.Ж. Теоретические основы воздействия наносекундных электромагнитных импульсов на процессы дезинтеграции и вскрытия тонкодисперсных минеральных комплексов и извлечения благородных металлов из руд: автореф. дис. ... д-ра техн. наук. - М., 2009. - 39 с.

В.С. Портнов, Л.К. Новикова, С.А. Выжва, Н.В. Рева, А.Р. Байжанова, В.М. Юров, Ә.Д. Маусымбаева

\title{
Нұрқазған кен орны Батыс бөлігінің минералдарының ұсақталуы мен ұнтақталуы
}

\begin{abstract}
Мақалада Батыс Нұрқазған кен орны минералдарының беттік энергиясы есептелген, ол $\sigma=0,806$ Дж/м ${ }^{2}$ тең. Батыс Нұрқазған кен орны минералдарының беттік энергиясына кварц $\left(\mathrm{SiO}_{2}\right)$ және корунд $\left(\mathrm{Al}_{2} \mathrm{O}_{3}\right)$ басты ықпал етеді. Нұрқазған кен орны минералдарының 1 т 5 мм ұсақ бөліктерге бөлудің жалпы жұмысы есептелген, ол $\mathrm{A}=3,014$ Дж-ге тең. Бұл нақты энергия тұтынуға $\mathrm{E}=30,2$ кВт-с/т сәйкес келеді, кенді бөлшектеу тиімділігін арттыру үшін минерал құрылымының ақаулығын арттыру қажет, температураны төмендетіп, бөлшектеу энергиясын арттыру керек. Кенді салқындатуда криогендік жабдықтар мен сұйықтықтарды қолдана отырып, бункерде орындаған тиімдірек. Бөлшектеу жұмысы мен минерал құрылымының ақаулығының жылдам өзгеруі энергияны оңтайлы пайдалануда кен өндіру немесе бункердегі электроимпульстік бөлшектеу кезеңінде жарылыс болу қауіпін туғызатыны көрсетілген. Түйіршіктің минималды өлшемі беттік энергиямен анықталады: mind $\rightarrow$ min $^{2}$. Бұл жағдай кеннің ұсақталу тиімділігін анықтайды. Оны артыру үшін минералдың беттік энергиясын төмендету қажет. Нұрқазған кен орнының Батыс және Солтүстік бөліктеріндегі кендерді бөлшектеу және ұсақтау үрдістерінің алдында оларды араластыру тиімді болып келеді.
\end{abstract}

Кілт сөздер: беттік энергиясы, кен, минералдық, ұсақтау, ұнтақтау, мыс, халькопирит, құрылым ақаулары. 


\title{
В.С. Портнов, Л.К. Новикова, С.А. Выжва, Н.В. Рева, А.Р. Байжанова, В.М. Юров, А.Д. Маусымбаева \\ Дробление и измельчение минералов западного участка месторождения Нурказган
}

\begin{abstract}
В работе рассчитана общая поверхностная энергия минералов месторождения Западный Нурказган, которая равна $\sigma=0,806$ Дж/м2. Основной вклад в поверхностную энергию минералов месторождения вносят кварц (SiO2) и корунд (Al2O3). Рассчитана общая работа на дробление 1 тонны минералов месторождения Нурказган до куска размером 5 мм, которая составляет A $=3,014$ Дж. Это соответствует удельным энергозатратам $\mathrm{E}=30,2$ кВт-ч/т. Показано, что для увеличения эффективности дробления руды необходимо увеличивать дефектность структуры минерала, энергию дробления и уменьшать температуру. Охлаждать руду лучше всего в приемном бункере, используя криогенные установки и жидкости. Показано, что резкого изменения работы дробления и дефектности структуры минерала можно достичь при оптимальном использовании энергии взрыва на стадии добычи руды или электроимпульсного дробления в приемном бункере. Определено, что минимальное значение размера зерна определяется поверхностной энергией $\min \mathrm{d} \rightarrow \min \sigma^{2}$. Это условие определяет эффективность измельчения руды. Для ее увеличения необходимо уменьшение поверхностной энергии минералов. Отмечено, что наиболее экономично смешивать перед процессами дробления и измельчения руды западного и северного участков месторождения Нурказган.
\end{abstract}

Ключевые слова: поверхностная энергия, руда, минерал, дробление, измельчение, медь, халькопирит, дефектность структуры.

\section{References}

1 Chanturiya V.A. Mining Journal, 2005, 12, p. 13-19.

2 Hague K.E. Int. J. Miner. Process, 1999, 57, p. 146-154.

3 Portnov V.S., Yurov V.M., Akhmetov A.S. The energy dispersion of refractory ores and minerals, Karaganda: KSTU, 2014,160 p.

4 The physical properties of rocks and minerals: Directory geophysics, ed. N.B.Dortman, Moscow: Nedra, 1984, 455 p.

5 Report on exploration at the deposit Nurkazgan reserves estimation as of 01.07.2004, the contract number 109 of 02/28/97, the Supplement to the contract number 984 of 18.09.02 In 8 books. Zhezkazgan, 2005.

6 Sazhin Yu.G. Ore preparation processes and equipment, Almaty: Kazakh National Technical University, 2011, 138 p.

7 Tataurov S.B. Notes of the Mining Institute, 2011, 190, p. 126-131.

8 Zaitsev A.V. Scientific Journal ITMO. «Refrigeration and AirConditioning» Series, 2014, 1, p. 6-12.

9 Kutuzov B.N. The methods of blasting. Part 2: Blasting operations in mining and industry, Moscow: Gornaya kniga, 2008,512 p.

10 Yusupov H.A., Kabetenov T. Technology shallow mining of ore deposits based on the separation of explosions, Almaty: Economics, 2013, 136 p. $324 \mathrm{p}$.

11 Kurets V.I., Usov A.F., Zuckerman V.A. Electropulse disintegration of materials, Apatity: Kola Science Centre RAN, 2002,

12 Rossi B.D., Pozdnyakov Z.G. Industrial explosives and blasting agents, Moscow: Nedra, 1971, 176 p.

13 Usov A.F., Efimov B.V., Zuckerman V.A. et al. Innovative potential of the Kola Science, Apatity: Kola Science Centre RAN, 2005, p. 306-312.

14 Popov V.V., Kizhaev S.A., Rud Yu.V. Solid State Physics, 2011, 53, 1, p. 70-74.

15 Andreev S.E., Perov V.A., Zverevich V.V. Crushing, grinding and screening of minerals, Moscow: Nedra, 1980, 415 p.

16 Alekseeva E.A. Getting siliceous raw aluminum in the ore preparation of low-quality bauxite, dis. ... cand. technical sciences, Saint Petersburg, 2015, 183 p.

17 Mishra B.K., Rajamani R.K. Comminution: Theory and Practice, ed. Kawatra, 1992, p. 427-440.

18 Mishra B.K., Rajamani R.K. Int J of Min Proc., 1994, 40, p. 171-186.

19 Mishra B.K., Rajamani R.K. Int J of Min Proc., 1994, 40, p. 187-197.

20 Radziszewski P., Tarasiewicz S. SAG'89 - Advances in autogenous and semiautogenous grinding technology, ed. Mular and Agar, Vancouver, 1989, p. 773-778.

21 Andrievsky R.L., Glaser A.M. Successes of physical sciences, 2009, 179, 4, p. 337-358.

22 Malygin G.A. Successes of physical sciences, 2011, 181, 11, p. 1129-1156.

23 Yurov V.M., Laurynas V.Ch., Guchenko S.A. Interuniversity collection of scientific papers «Physical and chemical aspects of the study of clusters, nanostructures and nanomaterials», Tver: Tver State. University, 2013, 5, p. 408-412.

24 Maksimov I.I., Otrozhdennova L.A., Tasin T.I., Zavarina R.I., Egorova V.G. Ore concentration, 2014, 3, p. 8-16.

25 Bunin I.Zh. Theoretical basis of the impact of nanosecond electromagnetic pulses on the processes of disintegration and break-up of fine mineral complexes and extraction of precious metals from ores, Abstract of doctor of technical sciences, Moscow, 2009, 39 p. 